\section{Science and War}

THE Association of Scientific Workers is organizing a public meeting and discussion on "Defence and the Responsibilities of the Scientist", to be held in the mathematics lecture theatre, Huxley Building, Royal College of Science, Exhibition Road, South Kensington, on Thursday, November 19, at 8 p.m. The chair will be taken by Prof. J. B. S. Haldane, and the speakers will include Prof. S. Chapman and Air Commodore I. E. O. Charlton. It is the purpose of the meeting to provide a forum for the full discussion of problems arising out of the increasing application of science to war. Measures that might be adopted by scientific workers as an organized body to further the cause of peace will also be considered.

\section{Announcements}

Ix is announced in The Times of November 6 that Dr. Edward Bohane, director of the Royal Dublin Society, is retiring from this post on a pension of $£ 1,900$ a year and a gratuity of 7,500 .

Mr. M. A. C. Hinton, deputy keeper of zoology in the British Museum (Natural History), has been elected zoological secretary of the Linnean Society for the remainder of the present session, in succession to Dr. Stanley Kemp, who has resigned.

Prof. L. A. Orbeli, of Leningrad, has been appointed a member of the Permanent International Committee of the Physiological Congresses in succession to Prof. I. P. Pavlov, who died last February. The Committee therefore is now constituted as follows : Profs. F. Bottazzi (Italy), W. B. Cannon (U.S.A.), O. Frank (Germany), A. V. Hill (Britain), secretary, B. A. Houssay (Argentine), Y. Kuno (Japan), L. Lapicque (France), G. Liljestrand (Sweden), and L. A. Orbeli (U.S.S.R.).

The following have been elected as officers of the Cambridge Philosophical Society for the year 193637: President, Dr. F. W. Aston; Secretaries, Dr. J. D. Cockeroft, Mr. A. H. Wilson, Dr. O. M. B. Bulman; New Members of Council, Prof. E. V. Appleton, Mr. G. E. Briggs, Dr. A. N. Drury, Mr. A. E. Ingham, Dr. D. Stockdale.

THE centenary of the foundation of the Army Medical Library of the United States, generally known as the Library of the Surgeon-General's Office, will be celebrated at Washington, D.C., on November 16, when Sir Humphry Rolleston will deliver an oration on its history with spècial reference to Billings, Fletcher and Garrison.

Prof, A. Butenandt, director of the Institute of Organic Chemistry of the Technical University at Leipzig, has been appointed director of the Kaiser Wilhelm Institute of Biochemistry at Berlin-Dahlem, and has been awarded the Rinecker Gold Medal by the University of Würzburg.

THE recent decline in the birth-rate in Japan is shown by the following figures: $1932,100,688$ births; 1933, 927,209 births; and 1934, 809,224 births.
Applications are invited for the following appointments, on or before the dates mentioned :

An agricultural organizer for Gloucestershire-The Clerk of the County Council, Shire Hall, Gloucester (November 16).

Two district officers in the Forestry CommissionThe Secretary, Forestry Commission, 9 Savile Row, London, W.1 (November 17).

A research bursar in physiology in the National Institute for Research in Dairying, Shinfield, near Reading-The Secretary (November 20).

A divisional engineer to the London County Council-The Clerk of the Council, County Hall, Westminster Bridge, London, S.E.1 (November 20).

A principal scientific officer, a senior scientific officer, a scientific officer (quote C.E. 6634/36) and a junior scientific officer (quote C.E. 6873/36), with qualifications in chemistry, physics, mathematics or engineering in the Admiralty Scientific Pool-The Secretary of the Admiralty (C.E. Branch), Whitehall, London, S.W.1 (November 21).

An assistant lecturer in engineering in the Brighton Technical College-The Education Officer, 54 Old Steine, Brighton (November 23).

A principal of the Luton Technical InstitutionThe Director of Education, Shire Hall, Bedford (November 24).

Two assistants (Grade II) (physics or chemistry) and one assistant (Grade III) (physics or chemistry) in the Explosives Directorate; and two scientific officers (mathematics), one scientific officer (engineering or mechanical sciences), one scientific officer (physics or electrical engineering), one assistant (Grade I) (physics or electrical engineering), one assistant (Grade II) (mathematics) and two assistants (Grade III) (physics or electrical engineering) in the Ballistic Directorate of the Research Department, Royal Arsenal, Woolwich, S.E.18-The Chief Superintendent (November 24).

A demonstrator in physics in the London (Royal Free Hospital) School of Medicine for Women-The Warden, 8 Hunter Street, Brunswick Square, W.C.1 (November 25).

A Stokes student for research in mathematical or experimental physics in Pembroke College, Cambridge - The Master (December 1).

A Tweedie exploration fellow in archæology and anthropology in the University of Edinburgh-The Secretary (May 12).

Mechanical and electrical engineers in the Royal Army Ordnance Corps-The Under-Secretary of State (A.C. 9), The War Office, London, S.W.1.

An economic geologist in the Mineral Resources Department (Intelligence Section) of the Imperial Institute, South Kensington, London, S.W.7-The Establishment Officer.

Veterinary officers in the Colonial veterinary service (vacancies in Malaya, East Africa and West Africa)-The Director of Recruitment (Colonial Service), 2 Richmond Terrace, Whitehall, S.W.1.

Assistant civil engineers in the drawing office of the Civil Engineer-in-Chief's Department, Admiralty, London, S.W.1. 